\title{
FAS/FASL gene polymorphisms in Turkish patients with chronic myeloproliferative disorders
}

\author{
Fusun Gediz Ozdemirkiran ${ }^{1}$, Sinem Nalbantoglu², Zafer Gokgoz³ ${ }^{3}$ Bahriye Kadriye Payzin ${ }^{1}$, \\ Filiz Vural ${ }^{4}$, Seckin Cagirgan ${ }^{5}$, Afig Berdeli
}

\begin{abstract}
'Department of Hematology, Atatürk Research and Education Hospital, Izmir Katip Çelebi University, Izmir, Turkey

2Department of Molecular Genetics, Faculty of Medicine, Ege University, Izmir, Turkey ${ }^{3}$ Department of Hematology, Baskent University, Adana, Turkey

${ }^{4}$ Department of Hematology, Faculty of Medicine, Ege University, Izmir, Turkey

${ }^{5}$ Department of Hematology, Izmir Medical Park Hospital, Izmir, Turkey
\end{abstract}

Submitted: 24 November 2014

Accepted: 18 March 2015

Arch Med Sci 2017; 13, 2: 426-432

DOI: https://doi.org/10.5114/aoms.2015.53963

Copyright $\odot 2016$ Termedia \& Banach

\section{Abstract}

Introduction: Chronic myeloproliferative disorders (CMPD) are chronic myeloid hematological disorders, characterized by increased myeloid cell proliferation and fibrosis. Impaired apoptotic mechanisms, increased cell proliferation, uncontrolled hematopoietic cell proliferation and myeloaccumulation may contribute to the pathogenesis of CMPD. The aim of our study was to show the possible role of FAS/FASL gene polymorphisms in CMPD pathogenesis and investigate the association with clinical parameters and susceptibility to disease.

Material and methods: We included 101 (34 polycythemia vera (PV), 23 primary myelofibrosis (PMF), 44 essential thrombocythemia (ET)) CMPD patients diagnosed according to the WHO classification criteria and 95 healthy controls in this study. All the patients and the controls were investigated for FAS/FASL gene expression, allele frequencies and phenotype features, and also FAS mRNA levels were analyzed.

Results: Chronic myeloproliferative disorders patients showed increased FAS-670AG + GG genotype distribution compared with the control group $(p<0.05)$. While the A allele was more frequent in both groups, AG genotype was more frequent in CMPD patients. There was no association between FAS-670A $>$ G gene polymorphism and some clinical parameters such as splenomegaly and thrombosis $(p>0.05)$. No statistically significant difference in FASL+843C>T genotype or allele frequency was found between groups $(p>0.05)$. Moreover, no statistically significant difference was detected in FASL and JAK2V617F mutations ( $p>0.05$ ). FAS mRNA expression was 1.5 -fold reduced in patients compared to healthy subjects.

Conclusions: According to our findings, FAS/FASL gene expression may contribute to the molecular and immunological pathogenesis of CMPD. More investigations are needed to support these data.

Key words: FAS/FASL, gene polymorphism, chronic myeloproliferative disorders.

\section{Introduction}

Chronic myeloproliferative disorders (CMPD) are pluripotent hematopoietic stem cell diseases, characterized by proliferation of one or more

\author{
Corresponding author: \\ Fusun Gediz Ozdemirkiran \\ Department of Hematology \\ Atatürk Research \\ and Education Hospital \\ Izmir Katip Çelebi University \\ 35370 Izmir, Turkey \\ Phone: +90 5336564720 \\ E-mail: mdfusun@gmail.com
}


myeloid cell lines (erythroid, granulocytic, megakaryocytic) in the bone marrow, without exhibiting any differentiation and maturation defect [1]. Common properties of these diseases include uncontrolled proliferation of one or more of the myeloid cell lines, relatively normal maturation, hepatosplenomegaly, transformation to acute leukemia in different proportions and development of bone marrow fibrosis [2]. Development, progression and myeloproliferative mechanisms of the disease are not quite clear yet. Molecular mechanisms as well as aberrant expression of the genes that regulate apoptosis are thought to play a role here too, as in other hematologic malignancies [3]. Impairment of the apoptosis mechanisms and aberrant expression of pro-antiapoptotic proteins contribute to the excessive cell proliferation and development of fibrosis [4]. The relationship between the impairment of apoptosis and various hematological malignancies (chronic neutrophilic leukemia, myelodysplastic syndrome (MDS), chronic myeloid leukemia (CML), etc.) has been revealed in the literature [5]. Apoptosis is known as programmed cell death $[6,7]$. It occurs through two main mechanisms: either a change in the mitochondrial permeability (intrinsic pathway) or binding of the death receptor and the specific ligand on the cell surface (extrinsic pathway) $[8,9]$. FAS (CD95) is a molecule expressed on the cell surface, and it initiates the death signal after binding to its ligand (FASL) [10]. The FAS/FASL pathway is a critical system for hematopoietic cell survival and apoptosis [11-13]. Genetic variations in the promoter region of FAS/FASL may play an important role in the pathogenesis of CMPD by inducing apoptosis. The aim of our study was to investigate the role of FAS/FASL gene polymorphisms in CMPD pathogenesis and their possible association with clinical parameters as well as susceptibility to the disease.

\section{Material and methods}

\section{Subjects}

One hundred and one patients with confirmed diagnosis of Philadelphia chromosome negative (Ph-) CMPD according to WHO criteria and 95 healthy volunteers were included in the study. Among 101 patients with CMPD, 34 had polycythemia vera (PV), 23 had primary myelofibrosis (PMF), and 44 had essential thrombocythemia (ET). Chronic myeloproliferative disorders patients who were regularly followed up in the hematology outpatient clinic and healthy volunteers with no history of systemic illness or systemic drug use were informed about the study in detail. The study was approved by the human research ethics committee of the hospital and informed consent was obtained from the patients and healthy volunteers who agreed to participate in the study. The patients' history, physical examination, clinical and laboratory findings (white blood count, hemoglobin, hematocrit, platelet count, iron, total iron binding capacity, ferritin, erythropoietin levels, cytogenetic and molecular examinations (Ph chromosome, Bcr-abl)) at the first diagnosis were recorded by the scanning hematology outpatient clinic follow-up program.

\section{Molecular methods}

\section{Genomic DNA preparation and quantitation}

Genomic DNA was extracted from EDTA-anticoagulated whole blood samples using a commercially available genomic DNA purification kit (Qiagen, Ontario, Canada) following the manufacturer's instructions. DNA concentration was determined spectrophotometrically by a NanoDrop digital spectrophotometer using the manufacturer's instructions and diluted as $100 \mathrm{ng} / \mu \mathrm{l}$. The isolated DNA $(2 \mu \mathrm{l})$ was loaded on $1 \%$ agarose gel to detect the quality of the DNA.

Polymerase chain reaction (PCR) amplification was carried out on a GeneAmp PCR System 9700 (PE Applied Biosystems, Foster City, CA, USA) in a $25 \mu \mathrm{l}$ reaction mixture in $0.2 \mathrm{ml}$ thin-walled $P C R$ strip tubes (Axygen Scientific, Inc, Union City, CA, USA) containing $1 \mu \mathrm{l}$ of genomic DNA solution, GeneAmp Gold Buffer $(15 \mathrm{mmol} / \mathrm{l}$ Tris $\mathrm{HCl}, \mathrm{pH}$ 8.0, $50 \mathrm{mmol} / \mathrm{KCl}$ ) (PE Applied Biosystems), $1.5 \mathrm{mmol}$ $\mathrm{MgCl}_{2}, 50 \mu \mathrm{mol} / \mathrm{l}$ each of deoxyGTP (dGTP), deoxy ATP (dATP), deoxyTTP (dTTP), and deoxyCTP (dCTP) (Promega, Madison, WI), 25 pmol each of forward and reverse primers and $1.0 \mathrm{U}$ AmpliTaq Gold polymerase (PE Applied Biosystems). The cycling conditions were initially $95^{\circ} \mathrm{C}$ for $10 \mathrm{~min}$, followed by 35 amplification cycles at $95^{\circ} \mathrm{C}$ for $45 \mathrm{~s}, 62^{\circ} \mathrm{C}$ for $45 \mathrm{~s}$, and $72^{\circ} \mathrm{C}$ for $45 \mathrm{~s}$, and a final extension at $72^{\circ} \mathrm{C}$ for $7 \mathrm{~min}$.

\section{Primers used for PCR-RFLP}

For FAS-670A $>G$ polymorphism the forward primer was 5'-CTA CCT AAG AGC TAT CTA CCG TTC-3' and the reverse primer was $5^{\prime}$-GGC TGT CCA TGT TGT GGC TGC-3'.

\section{Digestion protocol}

The amplified $331 \mathrm{bp}$ PCR product $(3 \mu \mathrm{l})$ was digested in a $10-\mu$ final reaction volume using $1 \mu \mathrm{l}$ of Reaction Buffer 2 and 5 units of Mval restriction enzyme (New England Biolabs, Beverly, MA, USA) at $37^{\circ} \mathrm{C}$ overnight. Controls of known genotype were included for every set of digestions carried out. After digestion, allele $G$ yielded three fragments of 99,188 , and $44 \mathrm{bp}$, whereas allele 
A yielded two fragments of 99 and $232 \mathrm{bp}$. Digested fragments were separated on $3 \%$ agarose gels and visualized after ethidium bromide staining in the BioDoc-It System (UVP, Upland, CA, USA) Bioimaging system.

\section{PCR-RFLP genotyping for $-843 \mathrm{C} / \mathrm{T}$ polymorphism of FASL gene}

Genomic DNA was amplified using PCR carried out on a Gene-Amp PCR System 9700 (PE Applied Biosystems). The cycling conditions were initially $95^{\circ} \mathrm{C}$ for $10 \mathrm{~min}$, followed by 35 amplification cycles at $95^{\circ} \mathrm{C}$ for $30 \mathrm{~s}, 45^{\circ} \mathrm{C}$ for $30 \mathrm{~s}$, and $72^{\circ} \mathrm{C}$ for $30 \mathrm{~s}$, and a final extension at $72^{\circ} \mathrm{C}$ for $10 \mathrm{~min}$. Forward (5'-CAA TGA AAA TGA ACA CAT TG-3') and reverse (5'-CCC ACT TTA GAA ATT AGA TC-3') primers were used according to the published sequence (GenBank accession number AF027385).

\section{Digestion protocol}

The amplified $114 \mathrm{bp}$ PCR product $(7 \mu \mathrm{l})$ was digested at $37^{\circ} \mathrm{C}$ for $3 \mathrm{~h}$ in a $20 \mu$ l final reaction volume using $2 \mu \mathrm{l}$ of Reaction Buffer 2 and 5 units of Dralll restriction enzyme (New England Biolabs, Beverly, MA). After digestion allele $T$ yielded two fragments of 98 and 16 bp, whereas allele $C$ was not digested and yielded as 114 bp. Digested PCR samples were subjected to electrophoresis on gels containing a mixture of 1.5\% agarose (Sigma, St. Louis, MO) and 1.5\% NuSieve GTG (BMA, Rockland, ME).

\section{RNA isolation from peripheral blood leukocytes}

Total RNAs were prepared from peripheral blood leukocytes (PBLs) by the Qiagen RNA Blood Mini Isolation Kit (Qiagen GmbH, Hilden, Germany). According to the manufacturer's instructions, $20 \mu$ of the obtained total RNA was denatured for $10 \mathrm{~min}$ at $70^{\circ} \mathrm{C}$ to prevent dimerization, then reverse transcribed in a total volume of $50 \mu \mathrm{l}$ containing $50 \mathrm{mM}$ Tris $\mathrm{HCl}(\mathrm{pH}$ 8.3), $75 \mathrm{mM} \mathrm{KCl}, 3 \mathrm{mM}$ $\mathrm{MgCl}_{2}, 10 \mathrm{mM}$ dithiothreitol, $0.5 \mathrm{mM}$ dNTPs, $15 \mu \mathrm{g} / \mathrm{ml}$ of random primers (Promega), 40 units of RNasin (Promega), and the RNA sample. Samples were incubated for 1 cycle in the thermal cycler for $10 \mathrm{~min}$ at $26^{\circ} \mathrm{C}, 60 \mathrm{~min}$ at $42^{\circ} \mathrm{C}$, and $5 \mathrm{~min}$ at $95^{\circ} \mathrm{C}$, and then finally cooled to $4^{\circ} \mathrm{C}$. Quantity and quality assessment of the obtained cDNA molecule was evaluated by the above method. Also, conventional PCR was performed with the newly designed RT-PCR primers for confirmation of the sequences.

\section{FAS gene mRNA expression quantitation by real-time $P C R$}

Relative quantification describes the change in expression of the target gene relative to the in- ternal reference gene. Reactions were performed in a $50 \mu \mathrm{l}$ volume of diluted cDNA sample, with $0.5 \mu \mathrm{M}$ specifically designed primers (NM 000043.4), and $4 \mathrm{mM} \mathrm{MgCl}$, by the Qiagen Quantitect Probe RT-PCR kit using ABI PRISM 7000. Cycling conditions consisted of $2 \mathrm{~min}$ at $50^{\circ} \mathrm{C}$, and 45 cycles of $10 \mathrm{~min}$ at $95^{\circ} \mathrm{C}, 15 \mathrm{~s}$ at $95^{\circ} \mathrm{C}$, and $1 \mathrm{~min}$ at $65^{\circ} \mathrm{C}$. A primer-probe set designed for human RNase $\mathrm{P}$, a housekeeping gene, was added to each sample to allow normalization to the total RNA content coamplifying with FAS as an internal control.

All of the genotyping was performed blinded with respect to subject characteristics, and blinded quality control samples were inserted to validate genotypes. One sample for each of the three possible genotypes had formerly been confirmed by sequencing and served as standards in the restriction analysis. Additionally, the genotypes for FAS and FASL genes identified by the PCR restriction fragment length polymorphism (PCR-RFLP) method were confirmed by DNA sequencing, and sequences were compared with the published FAS and FASL gene DNA sequences. Concordance for blinded samples was 100\%.

\section{Statistical analysis}

The Hardy-Weinberg principle [14] was used to test whether the patient and the control groups were balanced. Then, using the t-test and Pearson's $\chi^{2}$ tests, the patients' and subjects' genotype distribution and allele frequency were evaluated. The association of the genotype and allele frequency with the disease parameters was assessed by $\chi^{2}$ and one-way ANOVA tests. The statistical analysis was performed using SPSS and $p<0.05$ was considered statistically significant.

\section{Results}

A total of 101 CMPD patients who were diagnosed according to 2008 WHO criteria and were under the follow-up in Ege University Department of Hematology and 95 healthy volunteers (46 female/49 male, median age 49.4 years) were included in the study. Fifty of the patients were female and 51 were male, and the median age of the patients was 50.6 years. Age and gender features were homogeneous in the patient and the control groups (Table I). The demographic and clinical data according to each of the three CMPD groups is shown in Table II.

\section{FAS gene $-670 A>G$ polymorphism}

When comparing FAS gene $-670 A>G$ polymorphism genotype distribution between CMPD patients and the healthy control group, a statistically significant increase was found in $A G$ and 
GG genotypes in the patient group $(p=0.003$, Table III).

In the CMPD group, AG genotype was more prevalent, while the $A$ allele was detected more frequently in both groups. FAS gene $-670 A>G$ polymorphism and clinical findings such as splenomegaly and venous thrombosis showed no correlation ( $p=0.082, p=0.412$, respectively) (Table IV). In the comparison between ET, MF and $P V$ groups, no significant differences were detected regarding FAS gene $-670 \mathrm{~A}>\mathrm{G}$ polymorphism $(p>0.05)$ (Figure 1 ). Also, no statistically significant difference was found between FAS gene $-670 \mathrm{~A}>\mathrm{G}$ polymorphism and JAK2V617F mutation $(p>0.05)$. FAS mRNA expression was 1.5 -fold reduced in patients compared to healthy subjects and it was statistically significant $(p=0.003)$.

\section{FASL gene $843 \mathrm{C} / \mathrm{T}$ polymorphism}

CMPD patients and the healthy control group displayed no statistically significant differences in terms of FASL $843 C>T$ genotype distribution or allele frequency $(p=0.144)$ (Table $V)$. In both groups, CT genotype (46.5\% and $45.3 \%$ ) and the $C$ allele $(61.9 \%$ and $52.1 \%)$ were more common. FASL gene $843 \mathrm{C}>\mathrm{T}$ polymorphism and clinical findings such as splenomegaly and venous thrombosis showed no correlation $(p>0.05)$. Moreover, no statistically significant difference was detected for FASL and JAK2V617F mutations $(p>0.05)$. Statistical data of the correlation of FAS and FASL gene polymorphisms with clinical features in CMPD patients are shown in Table VI.

Table I. Demographic and clinical features of patients with CMPD and control group

\begin{tabular}{|lcc|}
\hline Features & $\begin{array}{c}\text { Patients } \\
(N=101)\end{array}$ & $\begin{array}{c}\text { Control } \\
\text { group } \\
(N=95)\end{array}$ \\
\hline Age (mean) [years] & 50.6 & 49.4 \\
\hline Gender (F/M) & $50 / 51$ & $46 / 49$ \\
\hline Essential thrombocythemia $(N)$ & 44 \\
\hline Polycythemia vera $(N)$ & 34 \\
\hline Primary myelofibrosis $(N)$ & 23 \\
\hline
\end{tabular}

Table II. Comparison of clinical and demographic features according to the three diagnoses

\begin{tabular}{|c|c|c|c|c|}
\hline \multicolumn{2}{|c|}{ Clinical and demographic features } & Myelofibrosis & $\begin{array}{l}\text { Essential } \\
\text { thrombocythemia }\end{array}$ & Polycythaemia vera \\
\hline \multicolumn{2}{|l|}{$\begin{array}{l}\text { Number of } \\
\text { patients }\end{array}$} & 23 & 44 & 34 \\
\hline \multicolumn{2}{|l|}{ Median age } & 55.17 & 48.09 & 50.79 \\
\hline \multirow[t]{2}{*}{ Gender } & Male & 11 & 18 & 22 \\
\hline & Female & 12 & 26 & 12 \\
\hline \multirow{3}{*}{$\begin{array}{l}\text { JAK2V617F } \\
\text { mutation }\end{array}$} & Negative & 10 & 31 & 5 \\
\hline & Homozygote & 1 & - & 1 \\
\hline & Heterozygote & 12 & 13 & 28 \\
\hline \multirow[t]{2}{*}{ Splenomegaly } & Negative & 4 & 42 & 10 \\
\hline & Positive & 19 & 2 & 24 \\
\hline \multirow[t]{2}{*}{ Thrombosis } & Negative & 21 & 32 & 22 \\
\hline & Positive & 2 & 12 & 12 \\
\hline \multirow[t]{2}{*}{ Hepatomegaly } & Negative & 13 & 40 & 26 \\
\hline & Positive & 10 & 4 & 8 \\
\hline \multicolumn{2}{|l|}{ Mean LDH } & 856.91 & 426.22 & 502.32 \\
\hline
\end{tabular}

LDH - lactate dehydrogenase: 125-220 U/l.

Table III. Genotype distribution and allele frequency of FAS gene 670A>G polymorphism in CMPD patients and healthy controls

\begin{tabular}{|lccccc|}
\hline Group & \multicolumn{3}{c|}{ Genotypes } & \multicolumn{3}{c|}{ Allele } \\
\cline { 2 - 6 } & AA & AG & GG & G & A \\
\hline CMPD & $32(31.7 \%)$ & $54(53.5 \%)$ & $15(14.9 \%)$ & $84(41.6 \%)$ & $118(58.4 \%)$ \\
\hline Control & $52(54.7 \%)$ & $30(31.6 \%)$ & $13(13.7 \%)$ & $56(29.5 \%)$ & $134(70.5 \%)$ \\
\hline
\end{tabular}


Table IV. Clinical and laboratory findings of CMPD patients according to FAS gene $-670 \mathrm{~A}>\mathrm{G}$ distribution

\begin{tabular}{|lccc|}
\hline Variable & $\begin{array}{c}\text { AA } \\
(N=32)\end{array}$ & $\begin{array}{c}\text { AG }+ \text { GG } \\
(N=69)\end{array}$ & $P$-value \\
\hline Splenomegaly & $18(56.3 \%)$ & $27(39.1 \%)$ & 0.082 \\
\hline Thrombosis & $10(31.3 \%)$ & $16(23.2 \%)$ & 0.412 \\
\hline
\end{tabular}

\section{Discussion}

In our study, increased Fas-670A $>G$ promoter polymorphism was found in the CMPD group compared to healthy controls. Also we investigated the possible relationship between Fas-670 gene polymorphism and clinical manifestations of CMPD. We did not find any correlation between the evaluated clinical findings (splenomegaly, thrombosis) and FAS gene $-670 A>G$ polymorphism. No significant difference between CMPD and healthy control groups was found in terms of FASL gene $843 C>T$ genotype and allele distributions.

In addition, FASL-843 gene polymorphism showed no association with the clinical parameters of



Figure 1. FAS 670 genotype distribution according to the patient disease groups: black - essential thrombocythemia; dark gray - myelofibrosis; light gray - polycythemia vera

disease. Comparing the patients with the control group, Fas mRNA expression was found to be $1.5-$ fold decreased among the patients. Apoptosis is a biological process which maintains homeostasis. Furthermore, abnormal regulation and dysfunctioning mechanisms play an important role in

Table V. Genotype distribution and allele frequency of FASL+843C>T in CMPD patients and healthy controls

\begin{tabular}{|lccccc|}
\hline Group & \multicolumn{3}{c|}{ Genotypes } & \multicolumn{2}{c|}{ Allele } \\
\cline { 2 - 6 } & CC & CT & TT & C & T \\
\hline CMPD $(N=101)$ & $39(38.6 \%)$ & $47(46.5 \%)$ & $15(14.9 \%)$ & $125(61.9 \%)$ & $77(38.1 \%)$ \\
\hline Control $(N=95)$ & $28(29.5 \%)$ & $43(45.3 \%)$ & $24(25.3 \%)$ & $99(52.1 \%)$ & $91(47.9 \%)$ \\
\hline
\end{tabular}

Table VI. Correlation of FAS/FASL gene polymorphism with clinical features in CMPD patients

\begin{tabular}{|c|c|c|c|}
\hline \multicolumn{2}{|c|}{ Clinical and demographic features } & \multirow{2}{*}{$\begin{array}{c}\text { FAS gene }-670 A>G \\
\text { polymorphism }\end{array}$} & \multirow{2}{*}{$\begin{array}{c}\text { FASL gene }-843 \mathrm{C}>\mathrm{T} \\
\text { polymorphism }\end{array}$} \\
\hline Gender & Male & & \\
\hline & Female & & \\
\hline Age & & $p>0.05$ & $p>0.05$ \\
\hline \multirow[t]{3}{*}{ JAK2V617F mutation } & Negative & $p>0.05$ & $p>0.05$ \\
\hline & Homozygote & & \\
\hline & Heterozygote & & \\
\hline \multirow[t]{2}{*}{ Hepatomegaly } & Positive & $p>0.05$ & $p>0.05$ \\
\hline & Negative & & \\
\hline \multirow[t]{2}{*}{ Splenomegaly } & Positive & $p>0.05$ & $p>0.05$ \\
\hline & Negative & & \\
\hline \multirow[t]{2}{*}{ Thrombosis } & Positive & $p>0.05$ & $p>0.05$ \\
\hline & Negative & & \\
\hline \multirow[t]{3}{*}{ Diagnosis } & Myelofibrosis & $p>0.05$ & $p>0.05$ \\
\hline & Essential thrombocythemia & & \\
\hline & Polycythemia vera & & \\
\hline
\end{tabular}


the development of many hematologic and solid malignancies [15]. A possible polymorphism in the Fas/FasL gene, which has an important task in this process, can result in hematological malignancies. Tognon et al. included $26 \mathrm{ET}, 12 \mathrm{PV}$ and $11 \mathrm{PMF}$ patients in their study examining expression of different apoptosis-related genes in patients with CMPD, and analyzed apoptotic genes, as well as the JAK2V617F mutation [16]. They detected increased expression of FAS, FASL, DR4, FAIM, and c-FLIP I in the CD34 positive cells of the CMPD group, compared with controls. Considering disease subgroups, they demonstrated increased FAS expression in PMF patients, compared to the ET group. Again, they investigated the relationship between the expression of apoptotic genes and JAK2V617F mutation and detected a positive relationship between FAS and DR5 expression and JAK2V617F mutation in patients with PV, whereas no statistically significant result was obtained in patients with ET and PMF. Zeuner et al. observed increased expression of FLIP in erythroid precursor cells of PV patients [17]. In the same study, they also determined the presence of the JAK2V617F mutation in PV erythroblasts. In patients with PV, resistance mechanisms against death receptor-mediated apoptosis have been claimed to have an important role in the pathogenesis of the disease. In another study supporting the effect of an impaired mechanism of apoptosis in CMPD, a balance between proliferation and apoptosis was demonstrated in patients with ET [18]. Despite precise biological and histopathological differences between ET and PMF, clinically different progression of these diseases may seem contradictory. No significant decrease was observed in overall survival of the patients with ET, whereas patients with PMF may experience a more progressive course of the disease and a poor prognosis. In recent years, bone marrow microenvironment remodeling and proliferative stress are considered to play an important role in the biology of ET and PMF. In the pathogenesis of these disorders, as a result of disruptions in apoptosis induction and regulation, decreased programmed cell death and increased proliferation can lead to clonal expansion. Only a few studies are available on platelet apoptosis and differentiation of megakaryocytes. Florena et al. investigated different immunophenotypic profiles in the megakaryocytes of patients with ET and PMF [19]. In the bone marrow biopsies of $30 \mathrm{ET}$ and 30 PMF patients, they analyzed expression of proapoptotic (FAS, FASL, Bax, Bad) and anti-apoptotic (Bcl-2, Bcl-XL, hTERT) molecules. Increased Bcl-XL expression was detected in the megakaryocytes of patients with ET, whereas increased expression of Bax and Bad was determined in megakaryocytes of PMF. FAS/FASL expression was not detected, while the mitochondrial pathway was emphasized to be critical for megakaryocyte apoptosis in both patient groups. Based on these results, increased expression of apoptotic molecules can support the fibrotic process in PMF, while the anti-apoptotic profile seen in ET was correlated with better prognosis. The role of Fas gene polymorphisms in the pathogenesis of different hematological malignancies was reported previously. Fare et al. investigated the FAS gene promoter $670 \mathrm{~A}>\mathrm{G}$ polymorphism in adult T-cell leukemia and compared the data with the control group, and identified AA genotypes more frequently among the patients [20]. Again, AA genotype has been associated with aggressive disease and poor prognosis, and Fas promoter polymorphism was considered to be associated with disease susceptibility, clinical signs, and survival in adult T-cell leukemia. Zhang et al. investigated the correlation between FAS promoter polymorphisms and cancer risk and retrospectively reviewed 11,461 cases of cancer in the electronic environment, and concluded that there was a high cancer risk related to FAS-1377 $A A$ genotype and smoking but no relationship with FAS-670 GG genotype [21].

In conclusion, we observed significantly higher FAS-670A $>G$ polymorphism frequency in patients with CMPD compared with the control group. This polymorphism should be investigated in larger patient groups in terms of its role in the pathogenesis of CMPD and its susceptibility to the disease.

\section{Conflict of interest}

The authors declare no conflict of interest.

\section{References}

1. Dameshek W. Some speculations on the myeloproliferative syndromes. Blood 1951; 6: 372-5.

2. Mesa RA, Verstovsek S, Cervantes F, et al. Primary myelofibrosis (PMF), post polycythemia vera myelofibrosis (post-PV MF), post essential thrombocythemia myelofibrosis (post-ET MF), blast phase PMF (PMF-BP): consensus on terminology by the international working group for myelofibrosis research and treatment (IWG-MRT). Leuk Res 2007; 31: 737-40.

3. Kaushansky K. The chronic myeloproliferative disorders and mutation of JAK2: Dameshek's 54 year old speculation comes of age. Best Pract Res Clin Haematol 2007; 20: 5-12.

4. Reed JC. Dysregulation of apoptosis in cancer. J Clin Oncol 1999; 17: 29-41.

5. Rozenfeld-Granot G, Toren A, Amariglio N, Brok-Simoni F, Rechavi G. Mutation analysis of the FAS and TNFR apoptotic cascade genes in hematological malignancies. Exp Hematol 2001; 29: 228-33.

6. Konopleva M, Zhao S, Xie Z, et al. Apoptosis. Molecules and mechanisms. Adv Exp Med Biol 1999; 457: 217-36.

7. Waring P, Müllbacher A. Cell death induced by the Fas/ Fas ligand pathway and its role in pathology. Immunol Cell Biol 1999; 77: 312-7. 
8. Arakaki R, Yamada A, Kudo Y, Hayashi Y, Ishimaru N. Mechanism of activation-induced cell death of T cells and regulation of FasL expression. Crit Rev Immunol 2014; 34: 301-14.

9. Villa-Morales M, Fernández-Piqueras J. Targeting the Fas/FasL signaling pathway in cancer therapy. Expert Opin Ther Targets 2012; 16: 85-101.

10. Reichmann E. The biological role of the Fas/FasL system during tumor formation and progression. Semin Cancer Biol 2002; 12: 309-15.

11. Tognon R, Nunes Nde S, Castro FA. Apoptosis deregulation in myeloproliferative neoplasms. Einstein (Sao Paulo) 2013; 11: 540-4.

12. Fulda S. Inhibitor of apoptosis (IAP) proteins in hematological malignancies: molecular mechanisms and therapeutic opportunities. Leukemia 2014; 28: 1414-22.

13. Scarfò L, Ghia P. Reprogramming cell death: BCL2 family inhibition in hematological malignancies. Immunol Lett 2013; 155: 36-9.

14. Hastings A. Hardy-Weinberg Theorem. Encyclopedia of Life Sciences 2001.

15. Wickremasinghe RG, Hoffbrand AV. Biochemical and genetic control of apoptosis: relevance to normal hematopoiesis and haematological malignancies. Blood 1999; 93: 3587-600

16. Tognon R, Gasparotto EL, Leroy JM, et al. Differential expression of apoptosis-related genes from death receptor pathway in chronic myeloproliferative diseases. J Clin Pathol 2011; 64: 75-82.

17. Zeuner A, Pedini F, Signore M, et al. Increased death receptor resistance and FLiP short expression in polycythemia vera erythroid precursor cells. Blood 2006; 107: 3495-502.

18. Tenedini E, Fagioli ME, Vianelli N, et al. Gene expression profiling of normal and malignant CD34-derived megakaryocytic cells. Blood 2004; 104: 3126-35.

19. Florena AM, Tripodo C, Di Bernardo A, et al. Different immunophenotypical apoptotic profiles characterise megakaryocytes of essential thrombocythemia and primary myelofibrosis. J Clin Pathol 2009; 62: 331-8.

20. Fare L, Bittencourt L, Silva-Santos G, et al. Fas-670 promoter polymorphism is associated to susceptibility, clinical presentation and survival in adult T cell leukemia. J Leuk Biology 2008; 83: 220-2.

21. Zhang Z, Xue H, Gong W, et al. Fas promoter polymorphisms and cancer risk: a meta-analysis based on 34 case-control studies. Carcinogenesis 2009; 30: 487-93. 